University of Texas at El Paso

\title{
DigitalCommons@UTEP
}

Open Access Theses \& Dissertations

2014-01-01

\section{Geophysical Investigation of Hot Springs in the Vicinity of Shoshone, California}

Felix Dziedzorm Ziwu

University of Texas at El Paso, fdziwu@miners.utep.edu

Follow this and additional works at: https://digitalcommons.utep.edu/open_etd

Part of the Geology Commons, and the Geophysics and Seismology Commons

\section{Recommended Citation}

Ziwu, Felix Dziedzorm, "Geophysical Investigation of Hot Springs in the Vicinity of Shoshone, California" (2014). Open Access Theses \& Dissertations. 1765.

https://digitalcommons.utep.edu/open_etd/1765

This is brought to you for free and open access by DigitalCommons@UTEP. It has been accepted for inclusion in Open Access Theses \& Dissertations by an authorized administrator of DigitalCommons@UTEP. For more information, please contact lweber@utep.edu. 


\title{
GEOPHYSICAL INVESTIGATION OF HOT SPRINGS IN THE VICINITY OF SHOSHONE, CALIFORNIA
}

\author{
ZIWU FELIX DZIEDZORM
}

Department of Geological Sciences

APPROVED:

Laura F. Serpa, Ph.D., Chair

Diane Doser, Ph.D.

Eric A Hagedorn, Ph.D.

Bess Sirmon-Taylor, Ph.D

Interim Dean of the Graduate School. 
Copyright (C)

by

\section{Ziwu Felix Dziedzorm}

2014 


\title{
GEOPHYSICAL INVESTIGATION OF HOT SPRINGS IN THE VICINITY OF SHOSHONE, CALIFORNIA
}

\author{
by \\ ZIWU FELIX DZIEDZORM, BSc.
}

\section{THESIS}

\author{
Presented to the Faculty of the Graduate School of \\ The University of Texas at El Paso \\ in Partial Fulfillment \\ of the Requirements \\ for the Degree of
}

MASTER OF SCIENCE

Department of Geological Sciences

THE UNIVERSITY OF TEXAS AT EL PASO

May 2014 


\section{ACKNOWLEDGEMENTS}

My sincere Gratitude to Dr. Laura Serpa for her support, understanding and guidance. To my committee, Dr. Diane Doser and Dr. Eric Hagedorn, for their professional advice. To Mr. Galen Kaip and Mr. Carlos Montana for their technical support and advice. My heart goes out to Victor Avila, Joel Castro, Ashley Nauer, Alejandro Rios and Alan Espino for their field support in making this research a successful one. Finally to my father Mr. Emmanuel KwadzoGa Ziwu and my wife Mrs. Esenam Adzo Ziwu their love and moral support. 


\begin{abstract}
Magnetic and gravity surveys were conducted in the vicinity of Shoshone, California to test a hypothesis from investigating hot springs within Tecopa and Saratoga which states that deep faults must intersect with a specific orientation relative to the regional stress field in order to create hot springs along the Amargosa River.
\end{abstract}

Three isolated basalt flows with different gravity and magnetic properties were identified near the Shoshone hot spring. Two of the flows have very low magnetic anomalies and the remaining one has a high magnetic anomaly. The high magnetic anomaly basalt flow also has a significantly higher Bouguer anomaly than the other two flows associated with the low magnetic anomalies. These observations suggest that the flows were formed by different time volcanic activity with the low magnetic anomaly basalts cooling during a magnetic reversal and the high magnetic anomaly basalt cooling during normal magnetic era. The deepest part of the Tecopa basin in the study area was identified as a region with low Bouguer anomaly and associated magnetic high. These properties suggest the basin fill includes highly vesicular basalts which would give the low density. Generally regions of high magnetic anomalies also have high Bouguer anomalies which indicate the possible existence of igneous rocks in the region. The low magnetic anomalies are mainly seen in the regions of thicker sedimentary deposits such as in the Resting Springs range where Precambrian and Paleozoic sedimentary rocks are preserved.

From the magnetic and gravity surveys, this research support the testing hypothesis based on the identified intersecting faults of the appropriate orientation associated with the Shoshone hot spring. Faults were also identified at places with no evidence of hot springs and this could be due to the presence of thicker sediments preventing the springs from flowing to the surface. An alternative possibility is that the faults are not deep enough to tap the hot water that would produce a hot spring. 


\section{TABLE OF CONTENTS}

ACKNOWLEDGEMENTS .................................................................................... IV

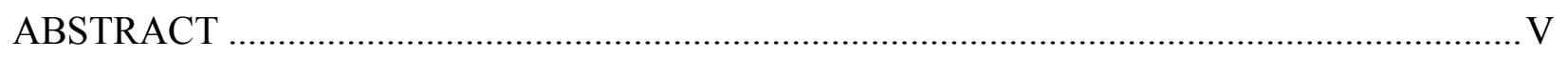

TABLE OF CONTENTS ..............................................................................................

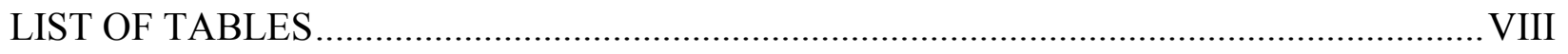

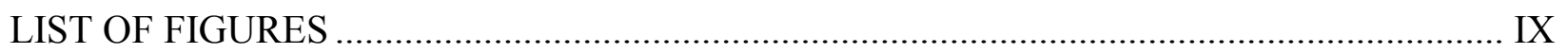

CHAPTER

1. INTRODUCTION ............................................................

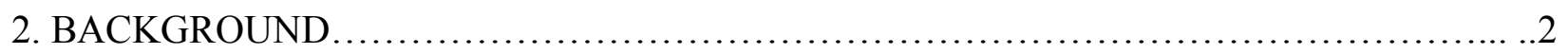

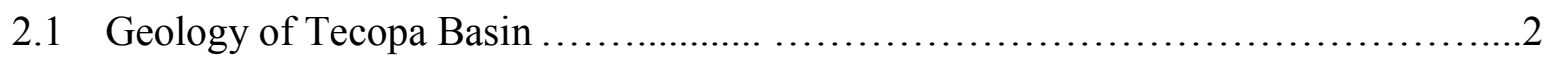

2.2 Previous Research......................................................

3. GEOPHYSICAL METHODOLOGY AND DATA ACQUISITION.......................9

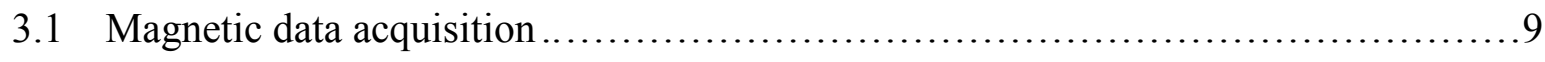

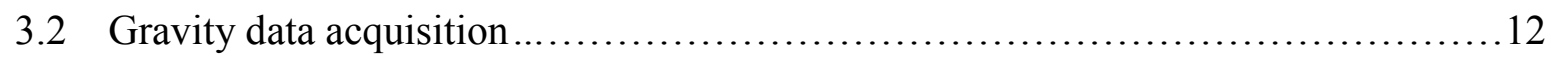

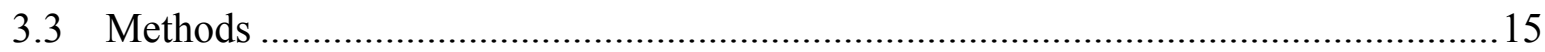




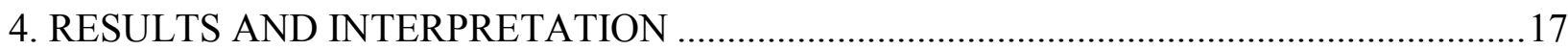

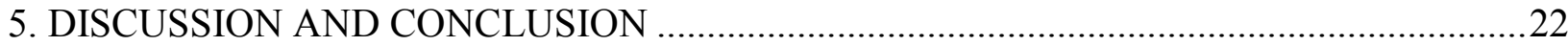

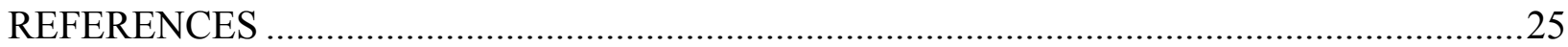

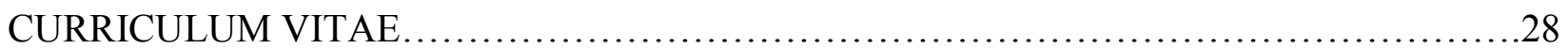




\section{LIST OF TABLES}

Table 1: Data sets merged to develop magnetic and gravity anomaly maps.......................10 


\section{LIST OF FIGURES}

Figure 1: Map of Tecopa basin (Modified from http:// gec.cr.usgs.gov). The study area is outlined in blue and the approximate area of the maps included in this paper is outlined with a dashed black line. .4

Figure 2: General geologic map in the vicinity of Shoshone (Modified from Hillhouse et al, 1987). ....5 Figure 3: General stratigraphic cross-section of the Tecopa Basin. Qtlm=Mudstone unit with tuffs A, B and C (Sheppard and Gude, 1968), Qtc=Conglomerate unit, TAu=Archean gneiss, Proterozoic and Paleozoic sedimentary rock $\mathrm{Qa}_{2}=\mathrm{Q}$ uaternary alluvium and $\mathrm{Qa}_{1}=$ Holocene alluvium. (Modified from

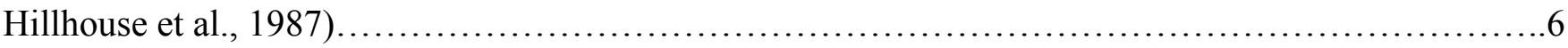

Figure 4: Magnetic anomaly map corrected for drift and diurnal errors..........................11

Figure 5. Bouguer anomaly map with the data sets from PACES website and and the ground data I collected for this study

Figure 6. Reduce to Pole magnetic map showing the variation of magnetic properties within Shoshone.

Different symbols shown on the map identifies the data set used.............................. 18

Figure 7. Overlay of Bouguer Anomaly (B.A) contours on Reduce-to- pole magnetic anomalies to

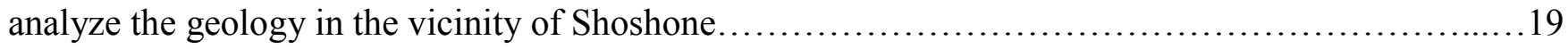

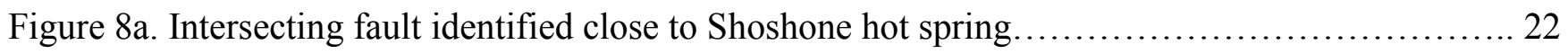

Figure 8b. Intersecting fault of the Tecopa hot spring (Wamalwa et. al., 2011).................... 23 


\section{CHAPTER 1}

\section{INTRODUCTION}

Shoshone, California, is located on the eastern side of the Death Valley National Park, within the Great Basin. It is the site of hot springs that appear to be part of a trend of intermittent hot springs along the Amargosa River. Walmawa and others (2011) suggest that hot springs in the nearby town of Tecopa and the Saratoga warm springs are controlled by intersecting deep faults that are oriented so that they create an opening for fluid migration in the current stress regime of the area. In this research I am testing this hypothesis by examining the location and orientation of faults in the Shoshone region and by looking for similar fault patterns in the approximately 25 $\mathrm{km}$ long river area where hot springs are not found between the towns of Shoshone and Tecopa. In order to evaluate the role of faulting in the locations of the hot springs, I have compiled regional ground and airborne magnetic and gravity data. Because the available data are widely spaced in my study area, I have also collected ground magnetic and gravity data to delineate the major trends in the area. The results of this study suggest that intersecting faults may play a role in the localization of hot springs as suggested by Wamalwa and others (2011) but the orientation of the faults are not consistent with their interpretation. I suggest that fracturing in the intersection zone, as well as fault orientations, may contribute to the hot spring locations. 


\section{CHAPTER 2}

\section{BACKGROUND}

Death Valley and the study area are part of the Eastern California Shear Zone (Dokka et al., 1993) which extends from the Mojave Desert region northward along the eastern side of the Sierra Nevada Mountains. This area appears to accommodate a significant part of the motion between the Pacific and North American Plates (Liu and others, 2010). The resulting deformation indicates a northwest extension direction that may be related to the hot spring occurrences along the river (Wamalwa et al., 2011).

\subsection{Geology of Tecopa Basin}

The Tecopa basin is located (figure 1) near the California-Nevada border in southeastern California. It is surrounded by the Greenwater, the Resting Spring and the Nopah ranges, as well as the Sperry, Ibex, Dublin, and Alexander hills. The Tecopa Basin has sparse vegetation which is characteristic of most arid climates. Shoshone and Tecopa are located along the Amargosa River which flows through the center of the basin. The Amargosa River is generally dry with some isolated springs that flow constantly.

The general geology of the basin includes crystalline basement, Pleistocene lacustrine sediments, Exhorheic pleistocene alluvial deposits, Holocene alluvial deposits and greenwater fans (figures 2 and 3). Gneiss is the oldest rock (basement) in the vicinity of the Tecopa Basin, and it is intruded by metadiorite dikes (Chesterman et al., 1973). A succession of upper Proterozoic to middle Cambrian marine sedimentary rocks is located along the eastern side of the Dublin Hills

and the Resting Springs Range. These marine sedimentary rocks are composed of Noonday 
Dolomite, Jonnie Formation, Stirling Quartzite, Wood Canyon Formation, Zabriskie Quartzite, Carrara Formation, and the Bonanza King Formation (Hillhouse et al., 1977). Volcanic ash in the basin has been chemically correlated (Hillhouse et al., 1987) to the Yellowstone and Long Valley eruptions, making it Tertiary in age.

The major deposits within the basin are conglomerate, mudstone, tufa and volcanic ash from Lake Tecopa (figure 3) which formed during the wet climate in the late Pliocene epochs. The presence of the authigenic silicate, located at the central section of the Tecopa basin gives a high level of salinity and alkalinity to the pore water in the region (Hillhouse et al., 1987).

Death Valley is the lowest and driest regions in the western hemisphere with an average of $5 \mathrm{~cm}$ of rainfall per year. Consequently, water travels from surrounding mountain ranges to Death Valley by underground conduits that consist of porous sedimentary rocks, fractures, and faults (Larsen et al., 2001; Hunt et al., 1996 and Miller, 1977). Most of the water passes below the Amargosa River which appears to follow a deep fault (Larsen et. al., 2001).

Hillhouse (1987) proposed that active extension and volcanism in the Tecopa basin ended around 4 Ma. That estimate was revised to approximately 7 Ma by Louie (1996) and Shields (1994) based on their geophysical studies of the geometry of the basin fill in the Tecopa Valley. Exposed volcanic rocks are generally assumed to be approximately 10 Ma. These age estimates suggest the igneous rocks are too old to be a likely source of heat for the hot spring waters so deep circulation along faults is considered more likely. 


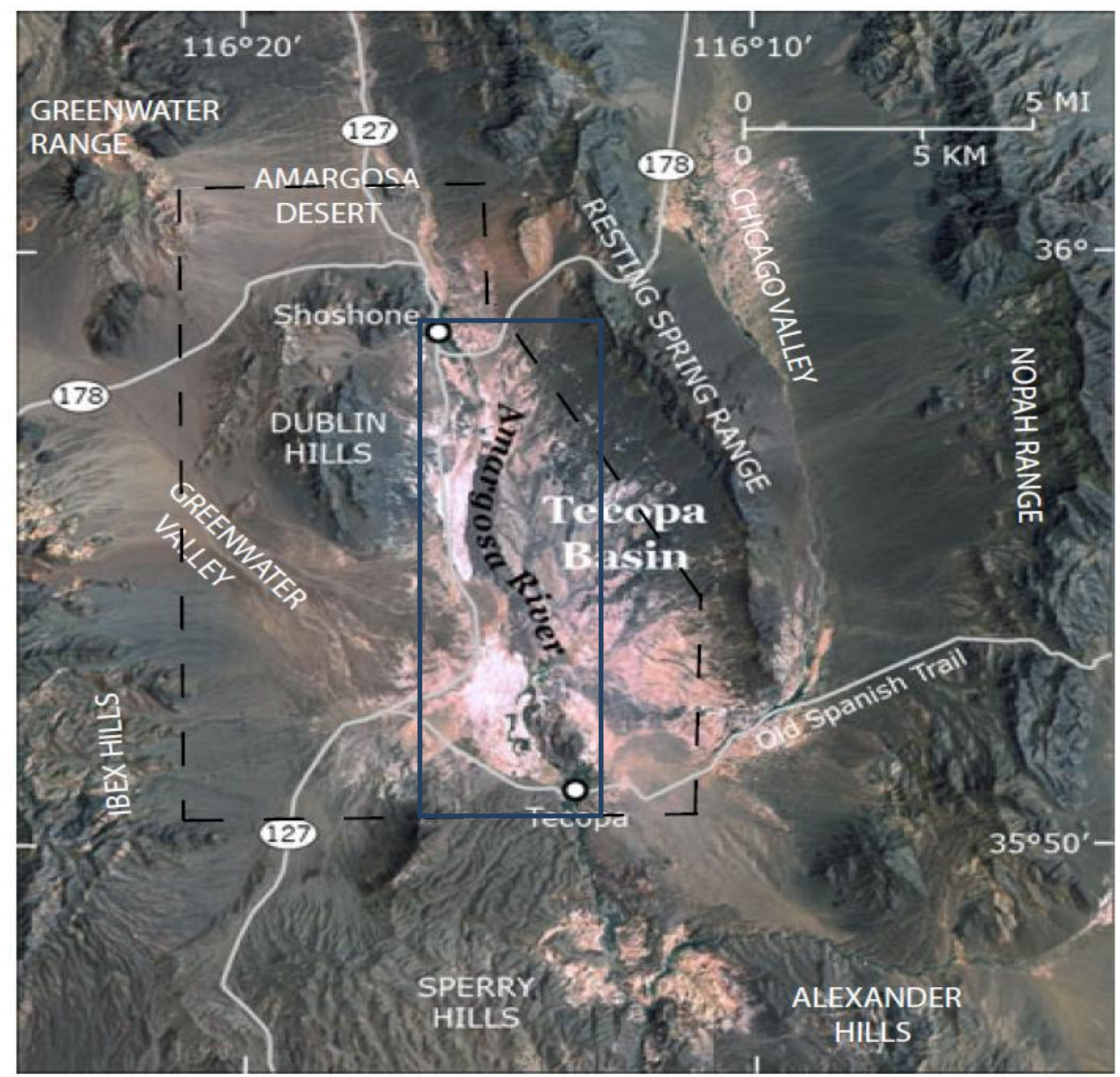

Figure 1: Map of Tecopa basin (Modified from http:// gec.cr.usgs.gov). The study area is outlined in blue and the approximate area of the maps included in this paper is outlined with a dashed black line. 


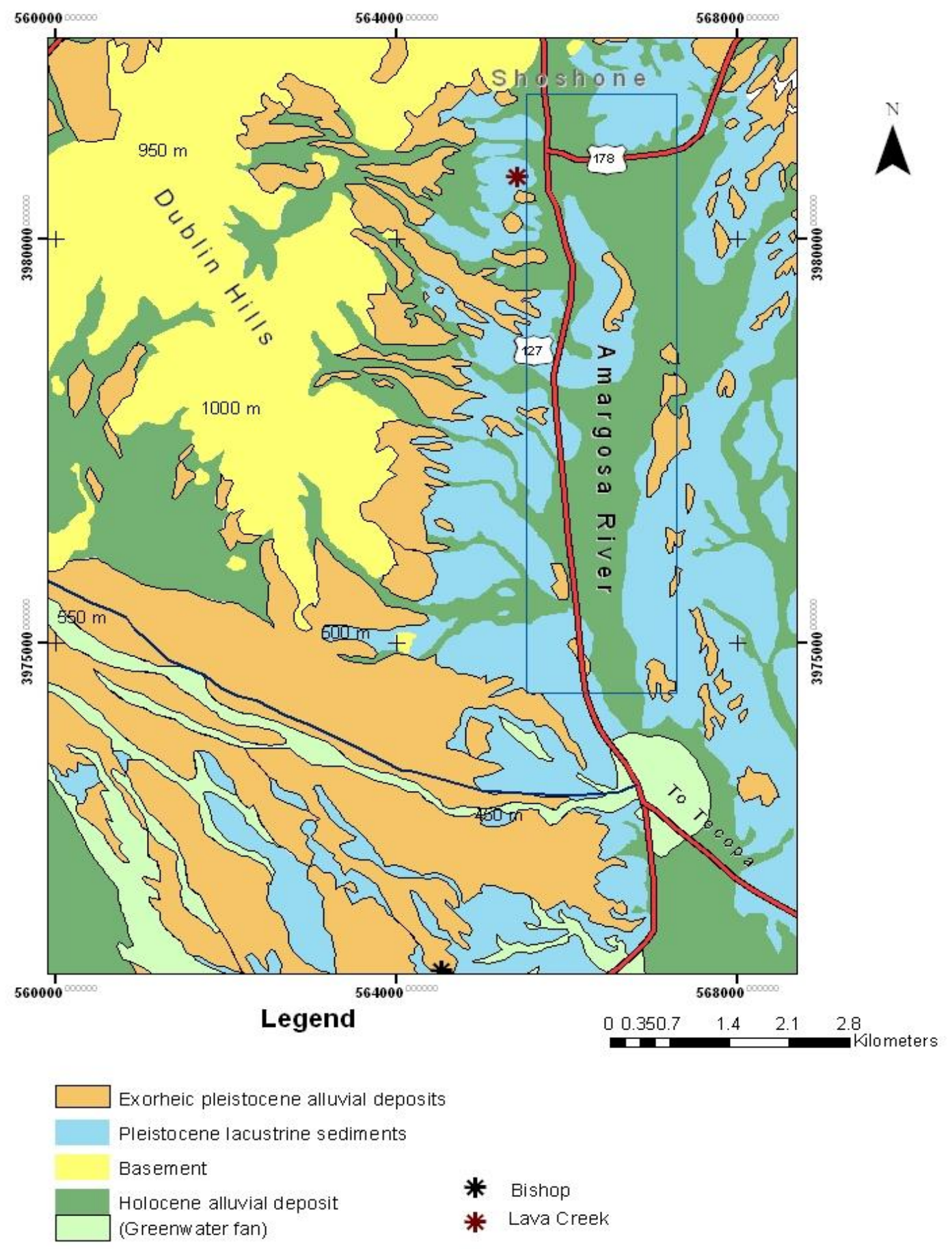

Figure 2: General geologic map in the vicinity of Shoshone (Modified from Hillhouse et al, 1987). 


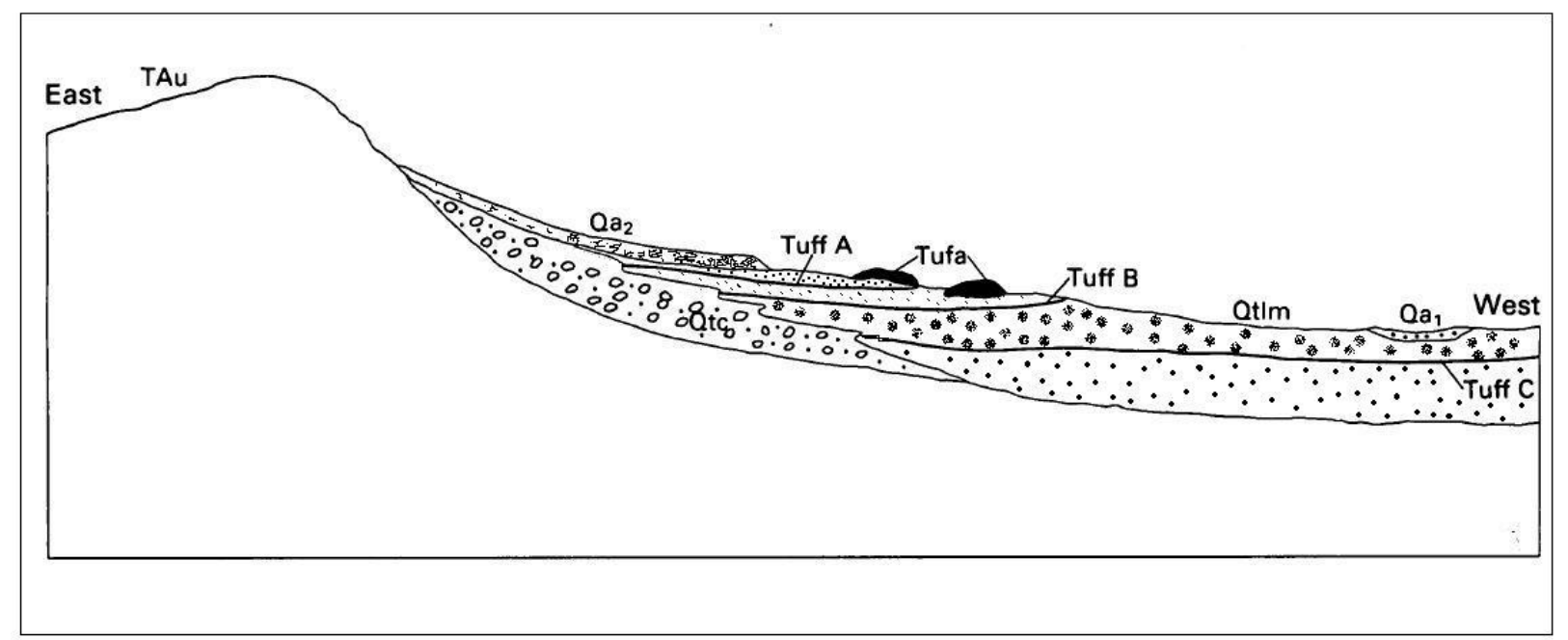

Figure 3: General stratigraphic cross-section of the Tecopa Basin. Qtlm=Mudstone unit with tuffs A, B and C (Sheppard and Gude, 1968), Qtc=Conglomerate unit, TAu=Archean gneiss, Proterozoic and Paleozoic sedimentary rock $\mathrm{Qa}_{2}=\mathrm{Quaternary}$ alluvium and $\mathrm{Qa}_{1}=$ Holocene alluvium. (Modified from Hillhouse et al., 1987)

If the Amargosa River fault were the conduit for the hot springs that rise to the surface then you would expect to find hot springs all along the river but, instead, the hot springs are limited to small areas around Saratoga and the towns of Tecopa, Shoshone, and Beatty on the eastern side of Death Valley. Research into the role of faulting in terms of the hydrological framework of Death Valley has been conducted by Wamalwa and others (2011) using electrical and magnetic data within the regions of Saratoga and Tecopa. They suggested that intersecting faults play a major role in the up flow of water because they are oriented so that the northwest oriented tensile stress field opens the conduits. In this research I used magnetic and gravity data to image the subsurface geology and identify intersecting faults within the research area to test this hypothesis. 


\subsection{Previous Research}

Various geophysical studies have been conducted in the Tecopa Basin (Louie, 1996; Serpa, 1988; Hillhouse, 1987; Wamalwa, 2011; Hussein, 2011) using gravity, magnetic, seismic reflection and electrical methods. The Consortium for Continental Reflection Profiling (COCORP) collected $250 \mathrm{~km}$ of deep crustal seismic reflection data in the Death Valley region (Serpa et al., 1988). Two of the seismic lines cross the Tecopa Basin. Those data in the Tecopa basin indicate faults penetrate to an approximate depth of $15 \mathrm{~km}$ (Serpa et al., 1988) where they flatten into a sub horizontal surface that could be part of the deep conduit for water migration.

Hussein and others (2011) used receiver functions, gravity and magnetic methods to image the structural properties of central Death Valley. From this research, the depth of the Moho was determine to be $24 \mathrm{~km}$ at the central part of the Death Valley basin, $33 \mathrm{~km}$ near my study area east of Death Valley. The densities of the various components of the crust were estimated to be $2900 \mathrm{~kg} / \mathrm{m}^{3}$ for the lower crust (gabbroic composition) and $2690 \mathrm{~kg} / \mathrm{m}^{3}$ for upper crust (quartzofeldspathic composition).

With faults penetrating from the subsurface of the Tecopa basin to about $15 \mathrm{~km}$ depth and the depth to the Moho within $33 \mathrm{~km}$ of the surface, there is the possibility of high heat transfer (thermal conductivity) along the faults. Additionally, the orientation of the stress fields along these faults can produce changes along these faults. These could have a huge impact on the temperature changes in the underground water flowing through these faults to the earth surface, hence the generation of hot springs in this region.

Faulted sediments cover the Tecopa basin and increase the porosity and permeability in the basin to allow the flow of ground water. The slightly faulted and tilted Holocene deposits of unconsolidated sand and gravels found in the Amargosa River provide evidence of faulting in 
that area and are believed (Hillhouse et al., 1987) to be the exit points of regional groundwater. The area of discharge of the groundwater in the Amargosa River is the Tecopa basin (Mifflin, 1988).

Larsen (2001) classified groundwater in Tecopa basin according to their hydrochemistry and stable composition to infer the chemical interaction and the direction of groundwater flow. These characteristics distinguish the sources of groundwater recharge and timing, water-rock interaction along flow paths and combining of distinct groundwater bodies. Generally, the temperature of these springs is from $17^{\circ} \mathrm{C}$ to $32^{\circ} \mathrm{C}$ but the Tecopa hot springs range from $9^{\circ} \mathrm{C}$ to $42^{\circ} \mathrm{C}$ (Larsen et al., 2001). 


\section{CHAPTER 3}

\section{GEOPHYSICAL METHODOLOGY AND DATA ACQUISITION}

Crystalline rocks generally have low permeability unless they are fractured. Fluids containing undissolved minerals may be heated as they circulate down along faults and are then trapped in the subsurface until they find a fault or fracture that allows the fluid to migrate back up to the earth's surface. The fluids will cool when migrating to the earth's surface and in so doing cause alteration of rock mineralogy. Minerals like iron in the form of magnetite and maghemite may be deposited along these faults and fractures in mainly sedimentary deposits or existing magnetite could be altered to a nonmagnetic iron oxide depending on the chemical composition of the fluids. Regions with exposed igneous rocks or highly susceptible basement rocks could influence magnetic signatures in a region. Additionally, fractures and faults exhibit a lateral density contrast with their surrounding rocks because they are filled with fluids and juxtapose rocks of different densities. In this research, gravity and magnetic methods were used to analyze the subsurface geology because they are the ideal methods for imaging density and magnetic variations in the shallow subsurface.

\subsection{Magnetic data acquisition}

The magnetic method is considered (Heiner and Wulf, 1968) to be one of the easiest and the least expensive geophysical methods to use. This method is used to identify contrasting magnetic properties in rocks or minerals especially those of intermediate to mafic composition due to the magnetic properties associated with their iron-rich composition. Variation in the earth's magnetic field can be due to changes in the iron content of the rock. I collected 505 ground magnetic data 
points in the area of research and merged them with other data sets (Table 1) to map (Figure 4) the geological features.

Table 1: Data sets merged to develop magnetic and gravity anomaly maps

\begin{tabular}{|l|c|c|}
\hline Data source & Magnetic Anomaly & Gravity Anomaly \\
\hline Shoshone (2000) & 88 & ----- \\
\hline Tecopa (2008) & 91 & ----- \\
\hline Obs_Ground_data (2012-2013) & 505 & 112 \\
\hline PACES & 106 & 80 \\
\hline Total & $\mathbf{7 9 0}$ & $\mathbf{1 9 2}$ \\
\hline
\end{tabular}

Two sets of GeoMetrics portable proton precession magnetometers model G-856 and a Garmin GPS system were used in this research. One of the magnetometers served as a base station instrument to monitor the diurnal variations in the magnetic field intensity and the other instrument served as a rover to collect readings at point stations within the area of research. Five readings were collected at each point and averaged to monitor local variations at the point's station. To supplement the ground magnetic data, aeromagnetic data were obtained from the United States Geological Survey and merged with the data collected here. 


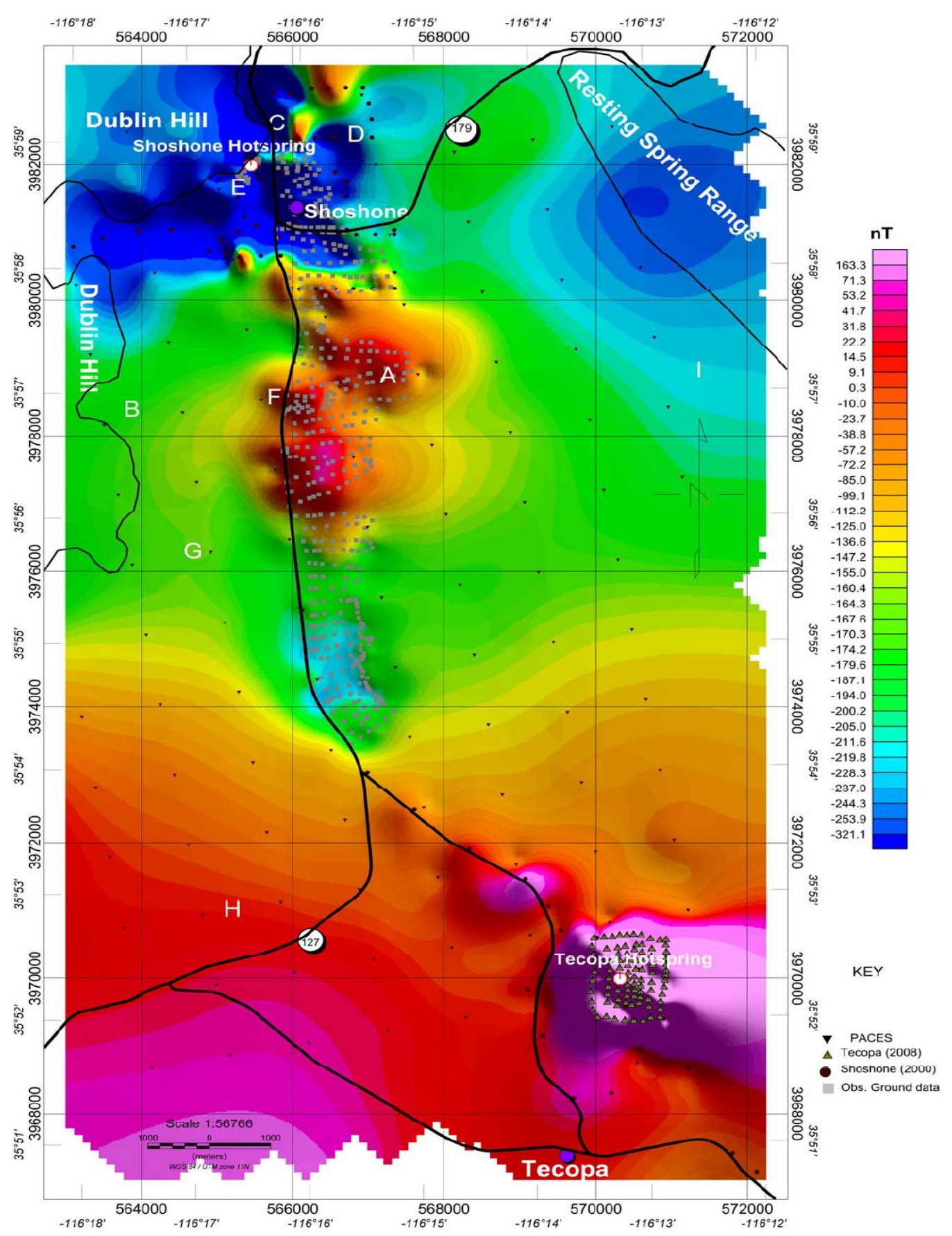

Figure 4: Magnetic anomaly map corrected for drift and diurnal errors.

The ground magnetic data were corrected for diurnal variation by correlating the time at which the magnetic reading of the points were observed to the same time the base station recordings were taken. The change in the magnetic value of the base station at the time of the recording of the magnetic rover reading was used to correct the diurnal effect. The resultant observed 
magnetic field data were then converted to residual magnetic anomaly values by removing the International Geomagnetic Reference Frame using Geosoft Oasis Montaj ${ }^{\mathrm{TM}}$ software.

The magnetic data used to construct the magnetic anomaly map (Figure 4) include four different surveys (Table 1). In addition to the ground magnetic data collected for this study, I extracted existing magnetic anomaly data from the Pan American Center of Earth and Environmental Studies (PACES) and used data collected by Serpa (unpublished) and by Wamalwa (2011) . A total of 790 data points were used to generate magnetic anomaly map (Figure 4) which stretches from Shoshone to Tecopa. The addition of the existing data sets to my data gives a better image of the trend of the magnetic variations and also give a general understand the magnetic signatures associated with hot springs. These data sets were merged by comparing the closest data points amongst different sets to correct for the offsets between them.

\subsection{Gravity data acquisition}

The gravity method is a passive method which involves measuring acceleration due to the earth's gravitational field. Lateral changes in density of the subsurface rocks in the vicinity of the measuring point will produce the variations in the measured gravity.

Gravity data for the region of interest were downloaded from the University of Texas at El Paso

(UTEP) PACES website for the research area. These data were used to generate a gravity anomaly map (Figure 5) to interpret the subsurface strata and anomalous features. The variations in the gravity anomalies were smooth because the spacing between adjacent points was rather in the spacing of $1 \mathrm{~km}$ and above which makes imaging small faults difficult. Gravity data were collected along several profiles using a Lacoste-Romberg gravimeter. The initial station spacing for profiles in the northern section of the area was approximately $200 \mathrm{~m}$. Later profiles had a 
spacing of about $400 \mathrm{~m}$ along each profile because we found that the additional time required to collect the closely spaced data was not justified by the scale of variations in the data.

A Topcon GB1000 GPS instrument was used for accurate position and elevation measurements. GPS raw data were furnished to National Geodetic Survey (NGS) under the National Oceanic and Atmospheric Administration (NOAA) to compute the horizontal coordinates (latitude and longitude) and the elevation. The horizontal coordinates were computed using the North American Datum of 1983 (NAD83) reference frame and later converted to metric units using the Universal Tranverse Mercator (UTM) system for zone 11N. The Orthometric height of each position was also determined using the North American Vertical Datum of 1988 (NAD88). The observed gravimeter readings were in Dial Units (D.U) and were converted into mGals during data processing.

Various factors such as instrument drift, diurnal changes, latitude, additional mass and elevation affect the gravity readings. Thus, gravity corrections were applied to reduce the data to the Simple Bouguer anomaly. A permanent NGA gravity reference station (1249-0 Shoshone Ca) with gravity value was reoccupied in the beginning and end of each section of the survey to correct for instrument drift and diurnal variations. Latitude, additional mass and elevation corrections are incorporated in the equation for determining the Simple Bouguer anomaly. I chose a density of $2670 \mathrm{~kg} / \mathrm{cm}^{3}$ with earth tide, instrument drift, free-air and Bouguer correction (Burger and others, 2006). The latitude changes were corrected by subtracting the regional gravity trend from the observed data. 


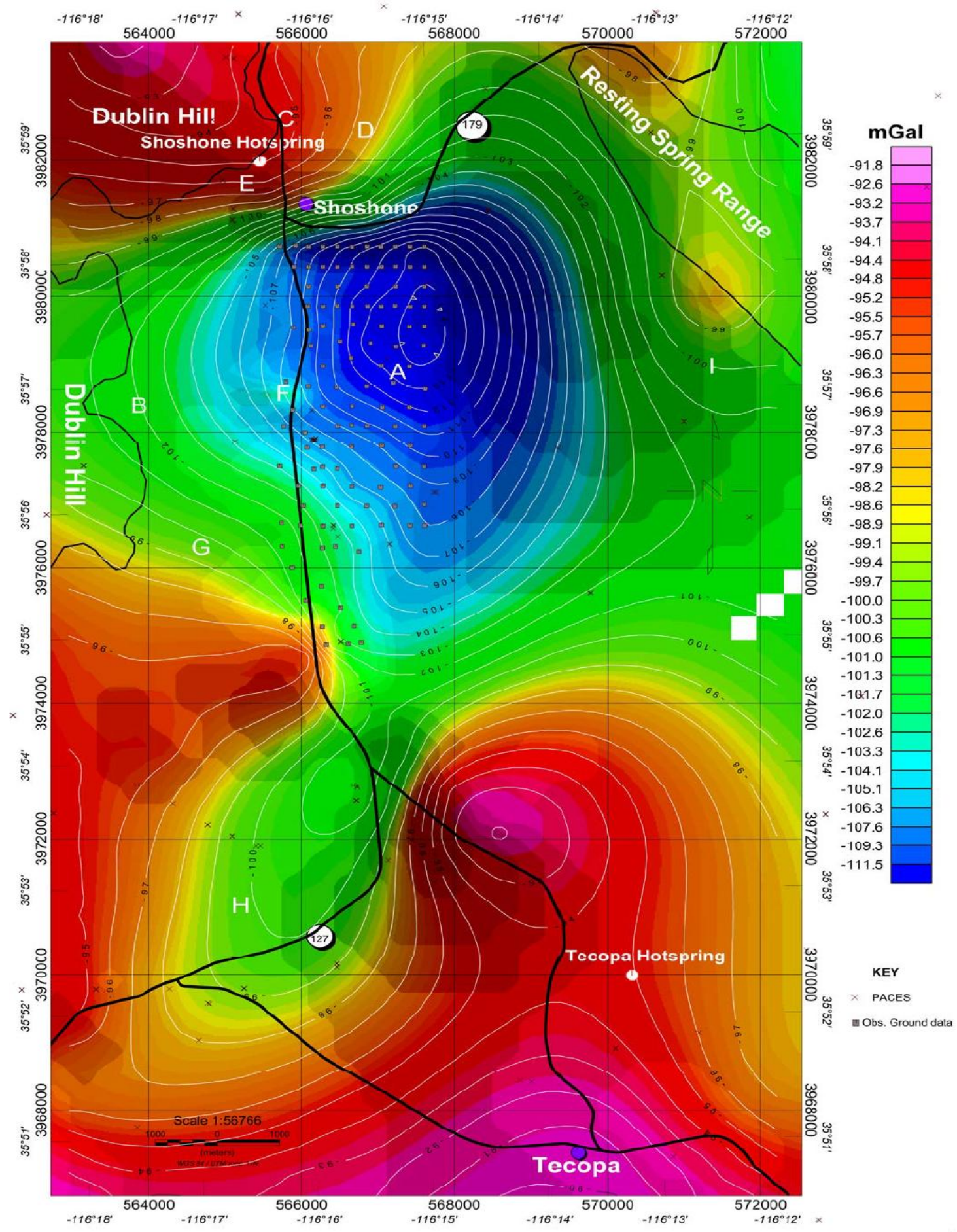

Figure 5. Bouguer anomaly map with the data sets from PACES website and and the ground data I collected for this study. 


\subsection{Methods}

Gravity and magnetic data are compared to the geological and structural information of the survey area in order to identify anomalies associated with subsurface features such as faults and fractures. Generally, gravity measurements across faults are lower on the downthrown block side than on the upthrown block side (Ponce and Langenheim, 1995). The degree of offset and depth of feature can be associated with the amplitude of the anomaly (Ponce and Langenheim, 1995).

Magnetic measurements across faults are complicated by the inherent directional property of rock magnetism as well as the induced and remnant components that make up the total magnetization. The induced magnetization is in the direction of the Earth's magnetic field, whereas the remnant magnetization can be in a completely different direction. The asymmetric dipolar nature of magnetic anomalies results in difficulties in interpreting the data (Ansari and Alamdar, 2009). Hence skill is required when using the magnetic anomaly to determine the approximate location and structure of the source (Ma et al., 2012).

Additionally, the interpretation of magnetic data is complicated by the superposition of multiple source responses and geological and cultural noise. These complications are reduced by the application of Reduce-To-Pole filtering to the data which simulates the magnetic response you would expect if your data had been collected at the north magnetic pole where the external magnetic field is vertical rather than inclined. A reduce-to-pole magnetic map (figure 6) moves the magnetic response for a subsurface object directly over the location of the object. This technique does not work well at low magnetic latitude $\left( \pm 20^{\circ}\right)$ regions because induced magnetic anomalies trending north to south are not detectable at zero geomagnetic inclination. However, 
this technique is applicable to my area of research and I use the reduce-to-pole magnetic anomaly map for the interpretation presented in chapter 4. 


\section{CHAPTER 4}

\section{RESULTS AND INTERPRETATION}

Figure 4 is magnetic anomaly maps which depicts the magnetic variation in the vicinity of Shoshone, developed from a merged magnetic anomaly data (table 1). Figure 6 is the reduce-topole magnetic anomaly map showing magnetic anomalies. The Simple Bouguer gravity anomaly map (Figure 5) is shown at the same scale as the magnetic data and figure 7 shows the gravity contours superimposed on the magnetic reduce-to-pole map to simplify the interpretation. The anomalies of interest in the maps are identified with letters A to I.

The Bouguer anomaly map (figure 5) displays a smooth trend with values ranging from -114.77 $\mathrm{mGal}$ to $-88.0 \mathrm{mGal}$. Low Bouguer anomalies are likely associated with the presence of unconsolidated sediments and sedimentary rocks (M. Hussein et al., 2011), or the presence of less dense tertiary volcanic rocks underlying the Holocene deposits which makes up the basin fill (Hillhouse et al., 1987). Alternatively, the low density within the basin can be associated with thicker pyroclastic sediments that are mainly less dense but have high magnetic susceptibility (Louie et al., 1996). Increasing Bouguer anomaly values indicate the presence of dense rocks consisting mostly of volcanic rocks or crystalline basement rocks. The carbonate sedimentary rocks that are common in the region may also produce gravity high because the density of carbonates can be similar to that of granite in many places (i.e. $\sim 2600 \mathrm{~kg} / \mathrm{m}^{3}$ ).

In the following section, I present my preliminary interpretation of the various anomalies based on the combined gravity and magnetic data (Figures 5, 6, and 7). 


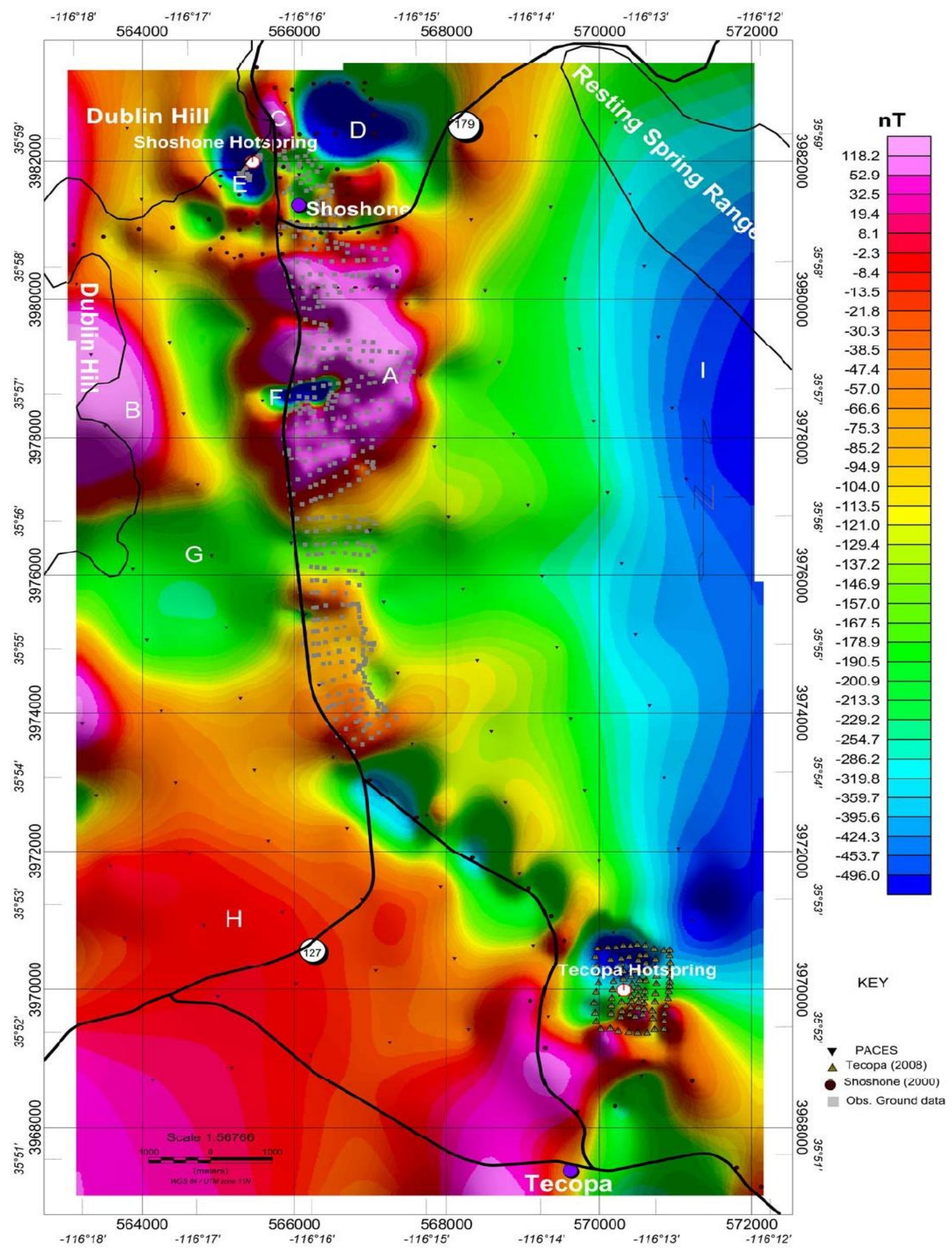

Figure 6. Reduce to Pole magnetic map showing the variation of magnetic properties within Shoshone.

Different symbols shown on the map identifies the data set used. 


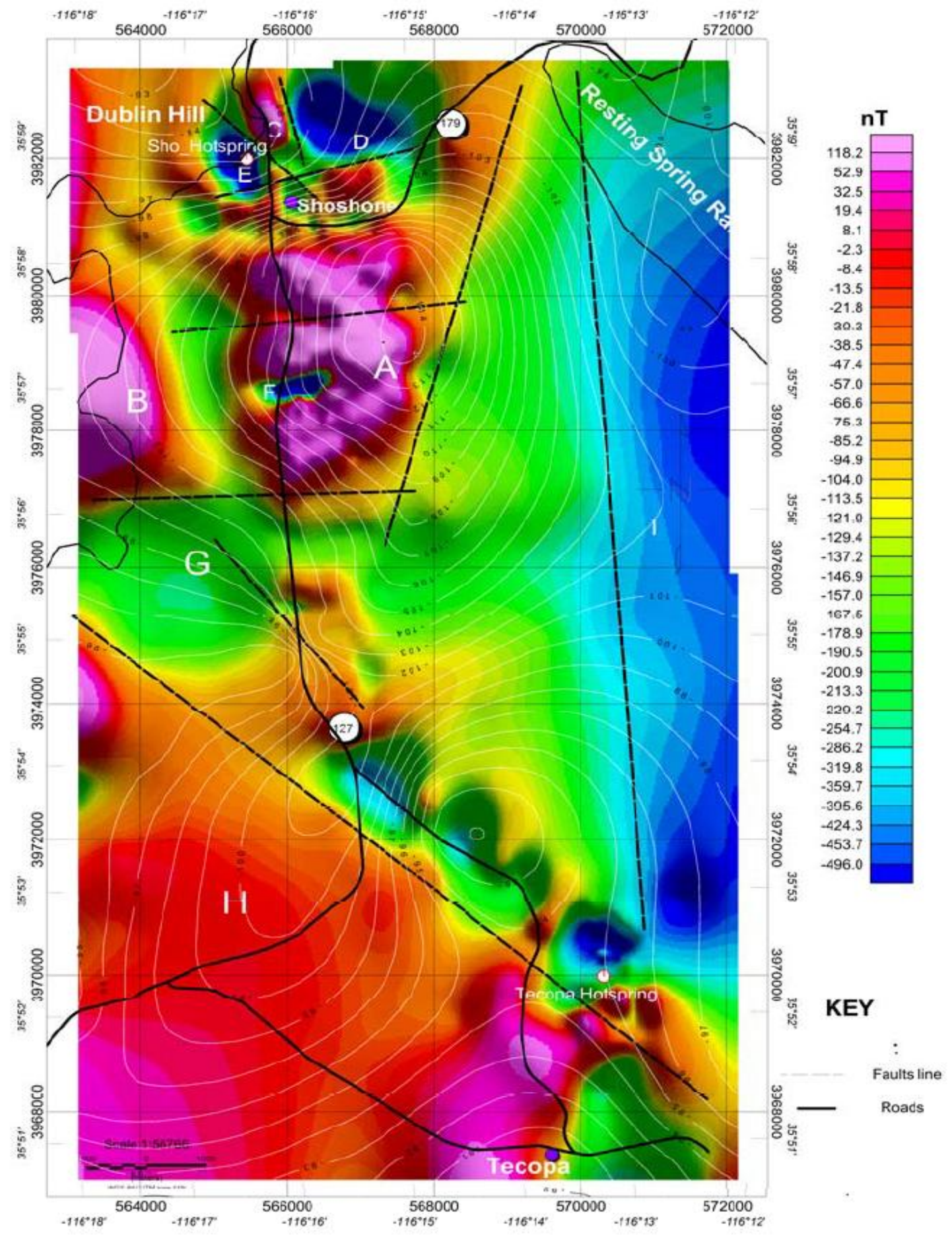

Figure 7. Overlay of Bouguer Anomaly (B.A) contours on Reduce-to- pole magnetic anomalies to analyze the geology in the vicinity of Shoshone.

Anomaly A: Area A is a high magnetic anomaly corresponding to a gravity low. Shallow igneous deposits may be present in this region because large deposit of pyroclastic tuffs covers 
almost all this section. It is possible that the low density pyroclastics contain sufficient iron to give rise to the magnetic high without also producing gravity high.

Anomaly B: High magnetic anomaly present in area B corresponds to a gravity gradient and is interpreted here to be related to the presence of basalts and the related tuffs of the Dublin Hill formation that directly overlie Paleozoic carbonate rocks on the western margin of the study area.

Anomalies C, D, AND E: This region lies along a gravity gradient that suggests faulting along the front of the Dublin Hills. Areas D and E are mainly composed of exposed basalts which overlie deformed lacustrine deposits of Pleistocene Lake Tecopa (Chesterman, 1973) with tuffaceous lake beds covering the remaining basalt deposition. The magnetic low signature of anomalies $\mathrm{D}$ and $\mathrm{E}$ may be an indication of the possible magnetic reversal that may have occurred during the cooling or formation of the basalts as a result of volcanic activity. Area $\mathrm{C}$ is also associated with surface exposures of basalt with the same geologic characteristics as areas D and $\mathrm{E}$, but it is a high magnetic and gravity anomaly. The magnetic properties of the three areas clearly indicated D and E may have formed during a magnetic reversal era while $\mathrm{C}$ may have occurred at a normal polarity era. The slight increase in gravity associated with anomaly $\mathrm{C}$ suggests it is a thicker or denser sequence of basalt than that found at D and E further supporting the idea that the deposits have different ages.

Anomaly F: There is a low magnetic anomaly region found in area F that is surrounded by high magnetic anomalies of region $\mathrm{A}$. The size and shape of the anomaly strongly suggest either a shallow nonmagnetic object or a reversely polarized igneous body. There is no distinct gravity anomaly associated with the magnetic anomaly and I suggest it is likely due to a relatively small reverse polarity dike within a broad region of tuffs and thin basalt flows. 
Anomaly G: Area G is an east-west trending magnetic low between two magnetic highs. It also corresponds to a gravity gradient with low gravity values to the north and high values to the south. The magnetic response may be due to the thick Holocene deposits along the Amargosa River with overlaying alluvial fans and small sand dunes. The east-west orientation of both gravity and magnetic gradients also strongly suggest a fault in this area that intersects the northsouth trending amargosa fault. This is one area that might be expected to produce hot springs but none are found in this region.

Anomaly H: Magnetic high covering majority of the area $\mathrm{H}$, the lower section of the map, can be identified with shallow Precambrian mafic crystalline basement rock and stretches widely within the Tecopa basin towards the Tecopa town.

Anomaly I: Magnetic lows on the eastern end of the map, labelled I, have little or no distinct gravity signature because of the lack of data in that area. The region is associated with the Precambrian through Paleozoic sedimentary rocks of the Resting Spring Range which are expected to have a low magnetic susceptibility.

Faults: Faults can be traced along regions with steep gradients of Bouguer anomaly or reduce-topole magnetic anomaly maps or a combination of both. A normal fault trending northeastern to southwestern can be identified on the eastern side of the area G. Intersecting faults are identified below the area $\mathrm{C}$. The Shoshone hot spring is located a little distance away from the intersecting faults. Additionally, hot springs seem to lie closely along the northwest to southeast trending component of the intersecting faults (fig. 6 and 7). 


\section{CHAPTER 5}

\section{DISCUSSION AND CONCLUSION}

Variations in the subsurface within the vicinity of Shoshone have been imaged using magnetic and gravity geophysical methods. These variations or anomalies are identified with different colors as shown on figures 4 to 7 . To give a better classification of anomalies as well as a good interpretation, the letters A to I are associated to the changes in magnetic as well as gravity anomalies. A larger portion of the region of the research has high magnetic anomaly values.

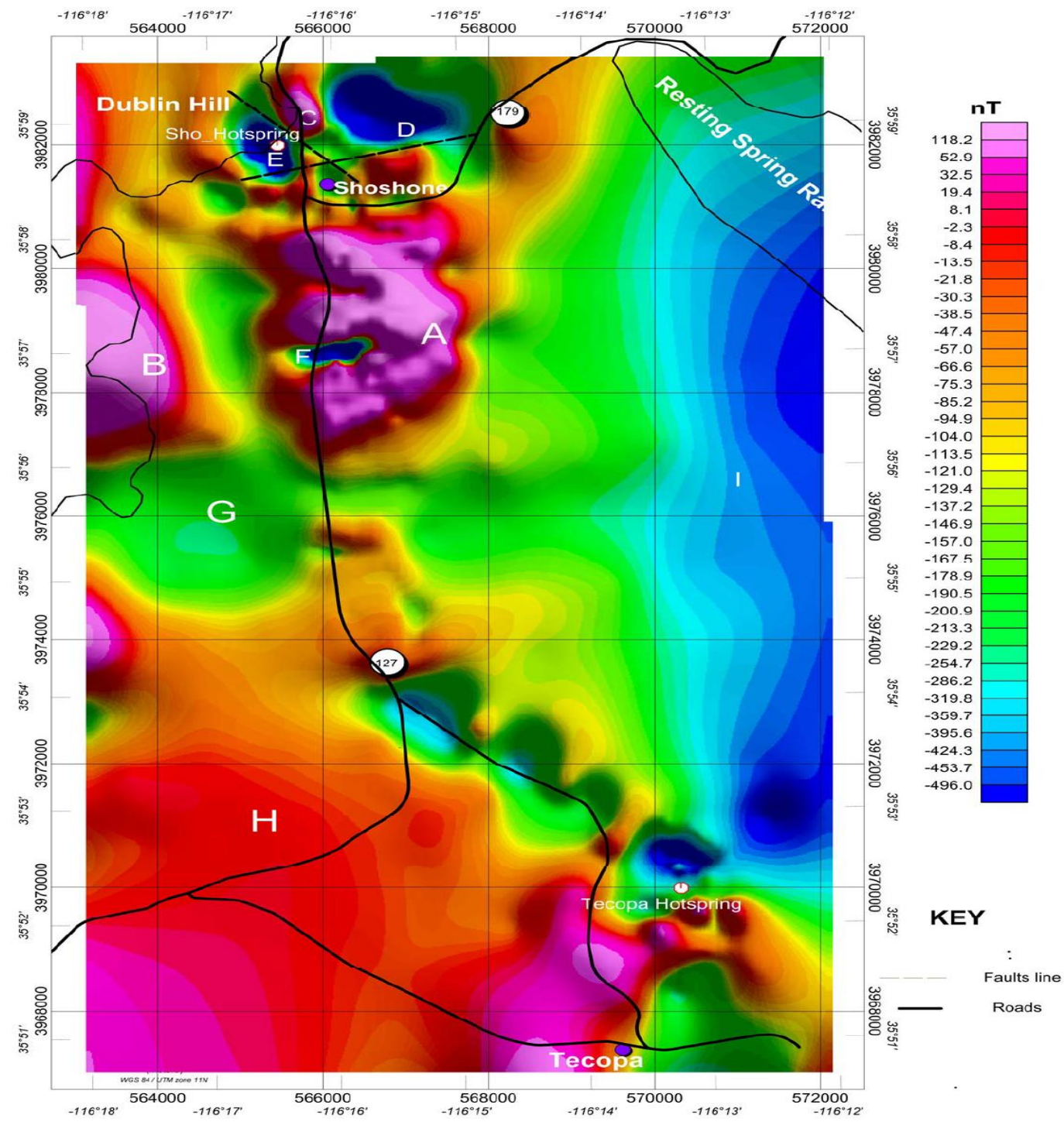

Figure 8a. Intersecting fault identified close to Shoshone hot spring. 


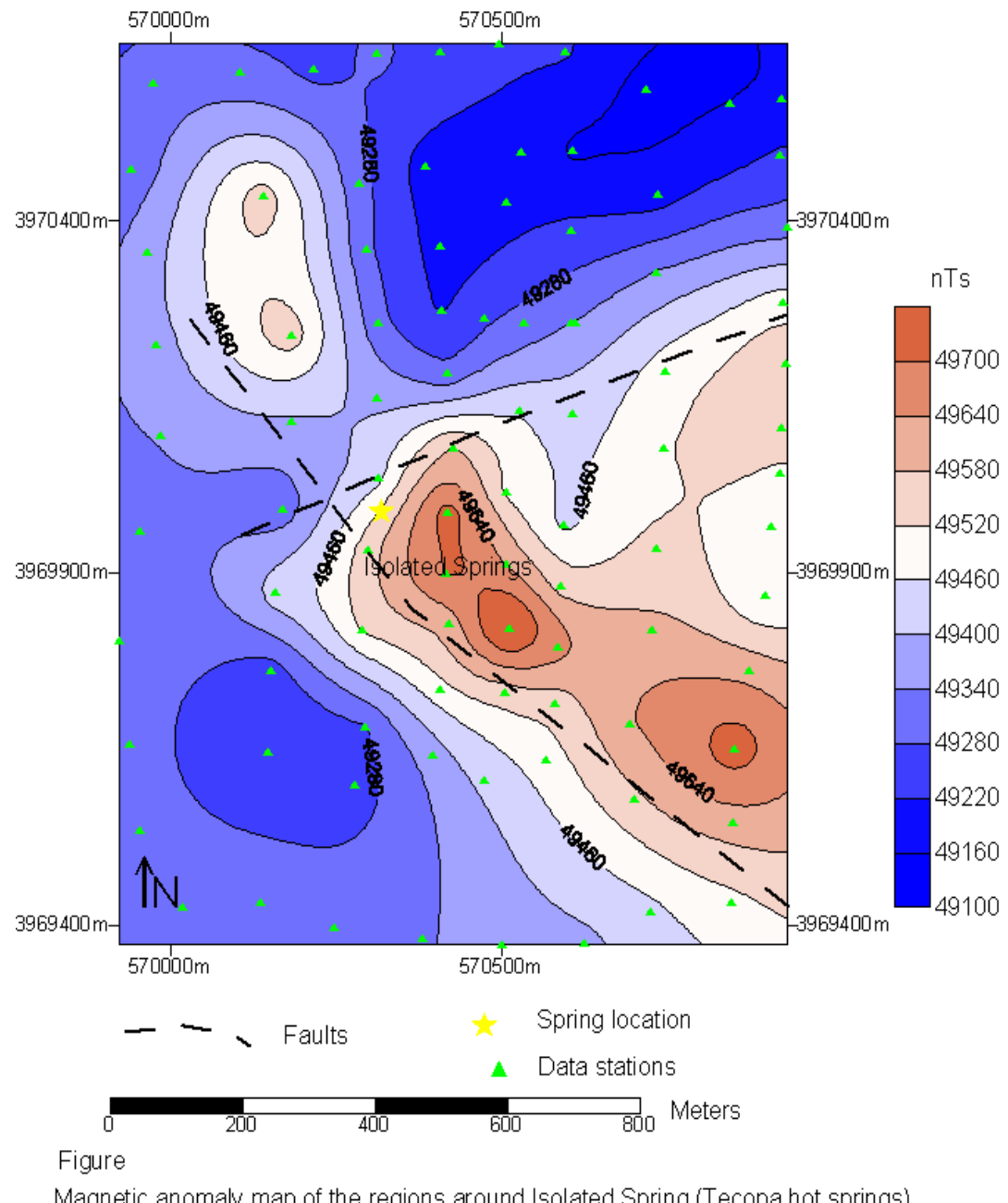

Figure 8b. Intersecting fault of the Tecopa hot spring (Wamalwa et. al., 2011).

This signature can mainly be associated with shallow Precambrian mafic crystalline basement rocks as well as intrusive basalts and related pyroclastic tuffs. These rock types are mainly characterized with higher density which contributes to high Bouguer anomaly values. Conversely, low magnetic signatures identified at sections with isolated exposed basalt rocks suggest a possible magnetic reversal of these basalts. The Bouguer anomaly values of these isolated basalts support the variation in their geophysical properties as well as their time of formation. The nonmagnetic rocks of the Resting Spring Range give a low magnetic anomaly 
response as indicated on the map (fig 6). Thick sediments along the Amargosa River are also associated with low magnetic anomaly values and low Bouguer gravity anomaly signatures. The low Bouguer anomaly within the central section identified as " $\mathrm{A}$ " is mainly associated with deeply buried basement rocks which can be identified as the location of the basin.

Faults were identified within the region with steep gradients along magnetic and Bouguer gravity anomalies. Three different intersecting faults are identified within the region of my research. The intersecting fault identified close to the Shoshone hot spring has one fault trending northwest to southeast and the other trending northeast to southwest. The orientation of the stress field looks similar to that identified by Wamalwa (2011) as shown in figures figure $8 \mathrm{a}$ and $8 \mathrm{~b}$ and can be inferred to lie along the regional North West direction in the Tecopa Basin (Wernicke et. al., 1982; Serpa and Pavlis 1996). The distance from the intersecting faults in Shoshone to the hot spring is greater (approximately $615.4 \mathrm{~m}$ ) compared to that in Tecopa (approximately $80.6 \mathrm{~m}$ ). However the extent of fracturing and interconnectivity of these fractures could influence the flow of the hot spring to the surface. The remaining intersecting faults have no activity of hot spring or any other geodynamic activity on the subsurface. It is possible that these faults are inactive or are not deep enough to support the generation of hot springs. Hence the hypothesis proposed by Walmawa 2011) has been supported by the magnetic and gravity anomalies identified along the Shoshone hot spring.

Further work on this research would be conducted along the three isolated basalts to authenticate the variations in their magnetic and gravity anomalies. To identify the vertical extent of the intersecting faults close to the Shoshone hot spring, a 2D model will be developed using GMSys. This will also help to understand the subsurface geology and possibly identify the channel through which this hot springs flow. 


\section{REFERENCES}

Burger, H. Robert, Sheehan, F. Anne, and Jones, H. Craig, 2006, Introduction to Applied Geophysics: Exploring the shallow subsurface. United State of America: W. W. Norton \& Company, Inc.. p356-364,

Chesterman, C. W., 1973, Geology of the northeast quarter of Shoshone quadrangle, Inyo County, California: California Division of Mines and Geology Map Sheet 18, Scale 1:24,000.

Dokka, R.K., 1993, The Original dip and subsequent modification of a Cordilleran detachment fault, Mojave extensional belt, California: Geology, v. 21, p.711-714.

Grauch, V. J. S., Hudson, M. R., and Minor, S. A., 2000, Aeromagnetic signatures of intrabasinal faults, Albuquerque basin, New Mexico: Implications for layer thickness and magnetization: 2000 Technical Program Expanded Abstracts, 70th Annual International Meeting, Society of Exploration Geophysicists, p. 363-366.

Heiner, L. E., and Wulf, S. A., 1968, Handbook of geophysical prospecting methods for the Alaskan prospector: University of Alaska Mineral Industry Research, MIRL Report No. 19.

Hillhouse, J.W., Ndombi, J.W.M., Cox, A., and Brock,A., 1977, Additional results on paleomagnetic stratigraphy of the Koobi For a Formation east of Lake Turkana (Lake Rudolf), Kenya: Nature, v. 265, p. 411-415.

Hillhouse, J.W., 1987, Late Quaternary Geology of the Tecopa Basin, Southeastern California: U.S. Geol. Surv. Map I-1728.

Hussein, M., Serpa, L., Doser, D. and Velasco, A., 2011, Imaging the Deep Structure of the Central Death Valley Basin Using Receiver Function, Gravity and Magnetic Data: International Journal of Geosciences, v. 2, no. 4, p. 678-688. 
Hunt, R.J., D.P. Krabbenhoft, and M.P. Anderson, 1996, Groundwater inflow measurements in wetland system: Water Res. Reseach 32, no. 3, 495-507.

Larsen, D., Swihart, G. H. and Xiao, Y., 2001, Hydrochemistry and isotope composition of springs in the Tecopa basin, southeastern California, USA: Chemical Geology, v. 179, p.17-35.

Liu, M., Wang H. and Li, Q., 2010, Inception of the eastern California shear zone and evolution of the Pacific-North American plate boundary: Journal of Geophysical Research, V. 115, B07401, 12 pp.

Louie, J. N., Ichinose, G., Shields, G., Hasting, M., Plank, G., and Bowman, S., 1996, Shallow geophysical characterization of the Pahrump Valley fault zone, California-Nevada border: L. A. Wright and B. W. Troxel, eds., Cenozoic Basins of the Death Valley Region: Geol. Soc. Amer. Spec. Pap., revised 1 June.

Ma Guo-Qing, Du Xiao-Juan, Li Li-Li, and Meng Ling-Shun, 2012, Interpretation of magnetic anomalies by horizontal and vertical derivates of the analytic signal: Applied Geophysics, Vol. 9, No. 4, P. 468-474, 5 Figures.

Mabey, D. R., 1963, Complete Bouguer anomaly map of the Death Valley region, California: U.S. Geological Survey Geophysical Investigations Map GP-305, scale 1:250,000, 1 sheet.

Mifflin, M.D., 1988. Region 5, Great Basin. In: Back, W., Rosenshein, J.S., Seaber, P.R. (Eds), Hydrogeology, The Geology of North America 0-2. Geological Society of America, Boulder, CO, pp. 69-78.

Miller, G.H., Andrews, J.T., and Short, S.K., 1977, The last interglacial-glacial cycle, Clyde Foreland, Baffin Island, N.W.T.: Stratigraphy, biostratigraphy, and chronology: Canadian Journal of Earth Sciences, v. 14. P. 2824-2857. 
Nilsen, T. H. and Chapman, R. H., 1974, Bouguer gravity map of California, Trona sheet: California Division of Mines and Geology, scale 1:250,000, 1 sheet, 9 p. text.

Ponce, D. A., Langeheim, V. E., 1995, Depth to pre-Tertiary basement in Southwest Nevada: American Nuclear Society proceedings of the Sixth Annual International Conference on HighLevel Waste Management, Las Vegas, Nev., 3p.

Serpa, L., de Voogd, B., Wright, L., Willemin, J., Oliver, J., Hauser, E., and Troxel, B., 1988, Structure of the central Death Valley pull-apart basin and vicinity from COCORP profiles in the southern Great Basin: Geol. Soc. Am. Bull., 100, 1437-1450.

Sheppard, R. A., and Gude, A. J. 3rd. 1968. Distribution and genesis of authegenic silicate minerals is tuffs of Pleistocene Lake Tecopa, Inyo County. California. U. S. Geol. Surv., Prof. Paper 597, 38 pp.

Shields, G., Allander, K., Brigham R., Crosbie R., Trimble, L., Sleeman, M., Tucker, R., Zhan, H., and Louie, J. N., Shallow Geophysical Survey Across the Pahrump Valley Fault Zone, California Nevada border: Seismological Society of America, v. 88, no.1, p. 270-275.

H.E. Ross; R.J. Blakely; M.D. Zoback, 2006, Testing the use of aeromagnetic data for the determination of Curie depth in California, Geophysics, 71, 5.

Wamalwa, A. M., Serpa, L. and Doser, D., 2011, Investigations of ground water flow associated with the Saratoga warm springs and the Tecopa Hot Springs near Death Valley, California, using magnetic and conductivity methods: Tectonophysics, v.502, p.267-275. 


\section{CURRICULUM VITAE}

Felix Dziedzorm Ziwu was born in Accra-Ghana in West Africa on September 231980. He attended Bishop Herman Secondary School for his senior secondary certificate. He continued to Kwame Nkrumah University of Science and Technology in the year 2001. He graduated with his bachelors degree in Physics in May 2005 with honors. He worked with E. K. Ziwu Surveying Services and also worked as a part-time lecturer at the Ghana School of Surveying and Mapping

until July 2011. In the fall 2011, he entered the Graduate School of University of Texas at El Paso. While pursuing a masters degree in Geophysics, he worked as a Teaching Assistant. He will continue for a $\mathrm{PhD}$ after completing his masters degree.

Permanent Address: P.O. Box MD 148, Madina-Accra, Ghana, West Africa

Ordziezi@yahoo.com 